Article

\title{
The Influence of the Sustainability Logic on Carbon Disclosure in the Global Logistics Industry: The Case of DHL, FDX and UPS
}

\author{
David M. Herold and Ki-Hoon Lee * \\ Griffith Business School, Griffith University, Brisbane, QLD 4111, Australia; david.herold@griffithuni.edu.au \\ * Correspondence: ki-hoon.lee@griffith.edu.au
}

Academic Editor: Marc A. Rosen

Received: 27 February 2017; Accepted: 8 April 2017; Published: 13 April 2017

\begin{abstract}
As a significant contributor to carbon emissions, global logistics companies are under scrutiny from various stakeholders, and respond by disclosing carbon-related information in the form of carbon reports. Carbon disclosure is, however, a mainly voluntary practice that allows for a broad range of interpretation from the management field, which leads to different approaches to the measurement and reporting of carbon-related information. From a theoretical perspective, these different carbon-disclosure approaches in global logistics companies can be attributed to the underlying construct of competing logics, namely the market and the sustainability logic. While competing logics are frequently discussed in the current literature, little is known about their influence on shaping carbon-disclosure practices. The aim of this paper is to examine the similarities and differences in the measurement and reporting of carbon-related information in order to capture the underlying logic that drives carbon-disclosure behaviour in the global logistics industry. We adopt an interpretative content analysis approach and examine the carbon-related information using the Carbon Disclosure Project (CDP) reports of DHL, FDX and UPS. The analysis reveals significant differences in the applied carbon-disclosure strategies, as well as in the degree of transparency between the three companies. The results also indicate that the carbon-disclosure practices of FDX are dominated by a market logic that emphasizes the economic benefits of carbon reductions, while DHL and UPS have prioritized the sustainability logic to gain a competitive advantage.
\end{abstract}

Keywords: carbon disclosure; sustainability reporting; sustainability logic; global logistics industry

\section{Introduction}

The risk of climate change has put sustainability high on the corporate agenda, and companies are under scrutiny from various stakeholders to disclose information about their carbon-related activities [1]. This is particularly the case for global logistics companies, as their output accounts for around 5.5 per cent of global carbon emissions [2,3]. Global logistics companies respond to these pressures by disclosing information in the form of carbon reports. However, carbon disclosure is still mainly a voluntary organisational practice, and global logistics companies can choose which tools or guidelines to apply in order to measure environmental and carbon performance [4]. This voluntary approach allows for a broad range of interpretation of carbon-related information, and leads to significant differences in carbon measurement and reporting, although the operations within global logistics companies can be regarded as broadly similar.

Although the 'Brundtland' report from 1987 [5] and the first United Nations climate convention framework from 1992 [6] acknowledged the need for carbon reporting in the transportation sector, little attention has been given specifically to carbon-disclosure practices in the logistics and transportation sector in the extant literature. Research on carbon disclosure and carbon management from the 
perspective of logistics companies is still limited [1,4,7-11]. The majority of existing studies address carbon issues either only partly, or do not focus specifically on logistics companies, pointing to a need to examine carbon-disclosure practices within the logistics and transportation sector. Such an examination and analysis of carbon-disclosure strategies in the logistics and transportation sector therefore complements the existing literature and provides new insights into this emerging field of carbon management.

Carbon-disclosure strategies on a firm level can be divided into two main approaches [12]. One is symbolic behaviour, which can be described as rhetorical statements to create an impression of environmental responsibility, but without relevant corporate action. The other is substantial behaviour, which reflects carbon-related accomplishments through instrumental corporate action that reduces carbon emissions and is congruent with societal expectations $[13,14]$. Although both approaches can be useful carbon-disclosure strategies, the symbolic and substantial approaches can be linked to different legitimisation 'rationales' within organisations, which are characterised by either a pragmatic or a normative view $[15,16]$. A normative rationale in carbon reporting can be linked to rather transparent behaviour to disclose corporate environmental activities and their consequences, while a pragmatic rationale may be regarded as an attempt to create an image for its audience; in such a situation, less is known about the company despite an openness to reporting [13].

It is argued that the different legitimation rationales, and subsequently the differences in carbon measurement and reporting, are related to the companies' different beliefs about the significance of carbon disclosure. Companies are constantly challenged to deal with carbon-related activities while at the same time being responsible for the (economic) wellbeing of their organization [17]. In the academic literature, this 'field of struggles' [18], which is represented by actors with multiple interests, is characterised by two coexisting but competing logics: the market logic and the sustainability logic. While the market logic is driven by economic gains, the sustainability logic within the global logistics industry is influenced by legitimacy-driven outcomes that go beyond pure cost savings initiatives [13,17]. Therefore, the stakeholders' demands for a dominant logic and their different approaches to carbon disclosure are embedded in an organisational context and, because each logic is associated with a different set of behaviours, the competing logics at the field-level influence carbon-disclosure practices at the firm level.

This paper therefore seeks to find some answers regarding how these competing logics shape carbon-disclosures practices in global logistics companies. In particular, the study aims to examine whether global logistics companies follow a symbolic or substantial measurement and reporting approach and what logic-market or sustainability-dominates the carbon disclosure behaviour. Adopting an interpretative content analysis approach embedded within a comparative case study, the carbon-related information of the CDP reports of global logistics companies DHL Express (DHL), Federal Express (FDX) and United Parcel Service (UPS) will be analysed and discussed. All three companies disclose carbon information, and are very homogenous in their operations; thus they represent an organisational field to explore carbon disclosure $[19,20]$. Moreover, differences in the measurement and reporting of carbon emissions in all three companies can be observed, making this specific industry within the global logistics industry a suitable example to examine carbon-disclosure practices. To examine the similarities and differences in the carbon reports and capture the companies' logic, this article applies specific measures related to carbon-related information and focuses on (1) each company's carbon strategy; (2) the extent of carbon information provided; (3) internal initiatives; and (4) external stakeholder engagement.

The article is structured as follows. The next section provides an overview of carbon reporting in the logistics industry and highlights the development and the general differences within carbon disclosure. This is followed by a review of the current literature, and a description of how different views of legitimacy are linked to the companies' carbon-reporting approaches. In the fourth section, we take the literature review further and introduce the institutional construct of competing logics as an underlying concept to explain the influences on the carbon-reporting approaches. The fifth section 
explains the methodology and the dataset. This is followed by an analysis and a discussion of the results with regard to carbon approaches and the related market or sustainability logic orientation. The final section discusses the limitations of this study and draws conclusions for further research and managerial implications.

\section{Carbon Reporting in the Global Logistics Industry}

Over the last two decades, the environmental and social consciousness of carbon-related issues have increased gradually in society, and revealed a potential legitimacy gap for companies and their carbon performance [13]. Fossil fuel-related sectors such as the logistics industry recognised that carbon constraints were a threat to existing business models and could not only generate significant impacts on markets and costs, but also lead to institutional pressures through regulatory policies. As a result, companies in the logistics industry acted to engage in a variety of voluntary schemes to inventory, curtail and trade carbon emissions [1]. Moreover, senior managers in these firms have interacted with each other quite frequently through various industry associations, conferences and climate negotiations, leading to some convergence in their perceptions of climate-change issues and of their interests. In a sense, these global industries and the 'issue arena' of climate change itself have become more important institutional influences on corporate strategy than the home country environment [21].

During the last decade, this development has led to an increasing number of locally and globally engaged environmental NGO groups, which have exerted pressure on companies to track and report their emissions by asserting that carbon management provides a mechanism for assessing climate-related business risks and opportunities [22,23]. In response to these stakeholder pressures, the disclosure of carbon-related information about the company's activities in the form of carbon reports has increased markedly over the last several years [2,4].

Transport and logistics activities, as facilitators of global trade, can be regarded as a significant source of carbon emissions. Global logistics activities comprise all our main transport modes (air, rail, road and ocean), and the resources and systems for the transportation of goods can be regarded as extensive in terminals, means of transportation and handling equipment [19]. The extensive use of the logistics and transportation network that depends heavily on fossil fuels consumption results in high carbon emission outputs, leading to scrutiny from stakeholders and an increasing adoption of carbon reporting within the global logistics industry $[1,24]$.

However, by bypassing formal regulatory mechanisms, carbon reporting can be regarded as a 'non-state market driven governance system' [25] or as a form of 'civil regulation' [26]. Its voluntary nature allows companies and management to choose which tools or guidelines to apply in order to measure carbon and environmental performance. For example, using The Greenhouse Gas Protocol: A Corporate Accounting and Reporting Standard (Revised Edition), companies can choose different carbon-measurement and reporting schemes for their carbon emissions [27]. DHL, FDX and UPS have integrated climate change into their strategies and follow The Greenhouse Gas Protocol, but a first glance reveals that although their operations can be seen as very similar, differences in measuring and reporting of carbon-activities can also be observed between the three companies [28].

An important point concerns the reporting of Scope 1,2 and 3 emissions within the global logistics industry. The Greenhouse Gas Protocol provided by the WRI/WBCSD [27] distinguishes three GHG emission categorising emissions into Scopes 1,2 and 3. Scope 1 emissions are all direct GHG emissions caused by owned or controlled facilities of an individually regarded company. Examples include the burning of fossil fuels, transportation by company-owned vehicles, and the chemical and physical processes necessary for producing electricity. Scope 2 emissions refer to indirect GHG emissions caused by the supply of purchased electricity generated outside the system boundaries. Scope 3 emissions are not caused directly by the company itself, but indirectly by its activities. This includes various categories such as purchased transportation, fuel- and energy-related activities, business travel, and so on. While Scope 1 and 2 reporting is mandatory, Scope 3 reporting is voluntary, and logistics 
companies use different approaches to measure the carbon output [24]. For global logistics companies, purchased transportation by air, rail, road and ocean accounts for the largest source of Scope 3 carbon emissions $[29,30]$.

Moreover, to measure the targets, FDX and UPS have implemented 'intensity' targets compared with 'absolute' targets. An 'absolute' target would reduce the total amount of carbon emissions, and there are management fears that this could constrain the companies' growth. Therefore, an 'intensity' target is preferred; this measures the target as a decline in carbon emissions relative to the level of logistical activity [31]. However, companies need to decide the variable against which the reduction will be measured. Although DHL, FDX and UPS have adopted the 'intensity' approach, their variables differ. FDX addresses only Scope 1 emissions and defines its carbon-reduction target in 'ton-miles' for its aircraft emissions and in 'miles per gallon' for its vehicle fleet [32]. DHL relates carbon emissions to the total square metres of space in its warehouses [33]. In addition, while UPS also addresses Scope 1 aircraft emissions in 'ton-miles', it has developed more detailed ratios for each Scope 1 and 2 emissions of its divisions and assigned each a different weighting factor [31,34].

Furthermore, differences can also be observed in the extent to which GHG emissions are included in the reporting [24]. When carbon reporting is examined in a logistics context, not only $\mathrm{CO}_{2}$ emissions, but all relevant GHG emissions, have to be taken into account; the relevant indicator to measure the impact of emissions on climate change is $\mathrm{CO}_{2}$ equivalents [35]. Apart from $\mathrm{CO}_{2}$ as the major emission, others include methane $\left(\mathrm{CH}_{4}\right)$, nitrous oxide $\left(\mathrm{N}_{2} \mathrm{O}\right)$, sulphur hexafluoride $\left(\mathrm{SF}_{6}\right)$, per fluorinated compounds (PFCs) and hydro fluorocarbons (HFCs) [36,37].

\section{Legitimation and Carbon Reporting Approaches}

The most common approach to the introduction of corporate reporting is to view disclosure as a reaction to environmental factors. Thus, disclosure can be regarded as a way to legitimize actions by the business through a social contract, where it agrees to perform various desired actions in return for approval of its objectives, other rewards and its ultimate survival [38]. Organisational legitimacy has long been acknowledged as crucial for the survival of any organization [39]. Legitimacy is "a generalized perception or assumption that the actions of an entity are desirable, proper or appropriate within some socially constructed system of norms, values, beliefs and definitions" [15] (p. 274). Legitimacy can also be regarded as the underlying rationale, or the dominant motivation, for carbon reporting $[1,4,13]$.

Legitimacy building in the traditional view of institutional theory can occur through isomorphic behaviour, in particular within the same organisational field. As DHL, FDX and UPS can be regarded as entities that constitute a single organisational field, these companies may increasingly resemble each other with converging perceptions of how to respond to climate change [40]. In other words, contemporary institutional theory indicates that organisational practices within a field, such as carbon reporting, are driven by isomorphism and become similar over time [20,41]. Thus, the adoption of carbon reporting within the same organisational field can either be related to some sort of power exerted from the industry or there must already exist a successful model of carbon reporting that can be reproduced. While the former mechanism leads to normative isomorphism (i.e., induced by the industry), the latter-the presence of successful models-leads towards mimetic isomorphism (i.e., induced by competitors). Coercive isomorphism (i.e., pressures induced by regulators) can be regarded as a subordinated mechanism in this study, as all companies in this narrow organisational field face similar institutional pressures.

As a consequence of isomorphic behaviour, DHL, FDX and UPS should respond to these pressures in the same way. However, although DHL, FDX and UPS have responded by providing carbon information in the form of carbon reports, the carbon reporting shows significant differences [28]. Thus, isomorphism can be regarded as only valid to a certain extent within the field (i.e., the depth of response to institutional pressures as well as the degree of legitimatisation varies across companies). That is, companies have different viewpoints and positions regarding the degree of legitimacy required in their 
carbon reporting. In general, two opposing legitimation approaches can be distinguished with regard to carbon reporting: 'pragmatic' and 'moral' legitimacy [13]. Hrasky [13] argues that moral legitimacy represents a normative orientation in an organisation and is acquired when the organisation's stakeholders make a favourable evaluation of the organisation and its actual accomplishments. In contrast, pragmatic legitimacy involves engaging in self-interested behaviour calculated to portray an image of the organization that is honest and trustworthy, sharing and promoting the values that the audience also values [15].

According to Hopwood [16], these opposing legitimisation 'rationales' consequently lead to different approaches in carbon reporting. While a moral legitimacy approach in carbon reporting can be linked to a rather transparent behaviour to disclose the corporate environmental activities and its consequences, a pragmatic legitimacy approach can be regarded as an attempt to create an image for its audience; here, less is known about the company despite an openness to reporting. Thus, each legitimisation approach may have a direct influence on the carbon reporting approach. Hrasky [13] and Kim, Bach and Clelland [14] link pragmatic legitimacy to a symbolic management approach and normative legitimacy to an action-oriented or substantial management approach. Symbolic behaviour in carbon reports may constitute rhetorical statements designed to create an impression of sustainable or environmental responsibility, which are not necessarily accompanied by corporate action $[13,14]$. Symbolic behaviour can also be related to reputation management, which Schaltegger and Burritt [42] describe as a company's focus on societal, political and media attention. In a symbolic or reputational approach, carbon-related activities and their reporting are closely linked to the PR department to gain the support of the company's most immediate audiences [13]. Similar to a pragmatic legitimisation approach, symbolic management can be regarded as self-interested or narcissistic behaviour in carbon reporting with more or less substantiated claims of carbon-related achievements [42]. In contrast, carbon reporting may reflect the substantial corporate action taken by a company to achieve carbon-related accomplishments such as reducing its carbon footprint [13].

Both carbon reporting approaches can be regarded as useful legitimation approaches. The specific nature of the disclosure response depends on the particular legitimation strategy and often reflects a mix of both approaches. However, while is it evident that the differences in carbon reporting are related directly to the different legitimation approaches, it is still unclear what drives the different legitimation rationales. As isomorphic behaviour is limited to explain these differences in carbon disclosure, it is argued that these rationales are related to the companies' different beliefs about the significance of carbon reporting-hence its underlying logics.

\section{The Influence of Underlying Competing Logics on Carbon Disclosure}

Instead of viewing the organisational field as an homogenous collection of organisational actors, we could take the view of Bourdieu and Wacquant [43], who argue that the organisational field can be seen as dynamic or even a 'field of struggles'. In this 'field of struggles', actors are engaged in "a war or, if one prefers, a distribution of the specific capital which, accumulated in the course of previous wars, orients future strategies" [18] (p. 86). The organisation field therefore becomes a locale in which actors' relationships eventually fight for the adoption of cultural-cognitive, normative and regulative structures that provide stability and collective meaning to social behaviour [44]. In other words, the adoption of organisational practices such as carbon reporting provides the organising principles for a field and reflects the "assumptions and values, usually implicit, about how to interpret organisational reality, what constitutes appropriate behaviour and how to succeed" [45] (p. 70). These discursive practices represent what is called an institutional logic in the literature. Institutional logics underpin the appropriateness of organisational practices in given settings and at particular historical moments, which are influenced by multi-level political, cultural and social aspects of organisational behaviour and phenomena [46].

The adoption of carbon disclosure in the global logistics industry can subsequently be regarded as the adoption of a sustainability logic, as heightened concerns about corporate carbon emissions 
have created a potential legitimacy gap [47]. While it can be acknowledged that adoption of carbon reporting in the broader context of sustainability represents the logic behind the search for legitimacy, companies are also driven by the logic of the market [48]. A market logic assumes that companies address sustainability issues only if this positively affects their financial performance, such as profits or shareholder value [17]. Managers are constantly challenged to deal with sustainability while at the same time being responsible for the economic wellbeing of their organization, so are embedded in this 'field of struggles', where multiple stakeholders fight for their dominant logic and attempt to transform the company's structures and norms by a "political process that reflects the power and interests of organized actors" [49] (p. 658). As a consequence, organisational responses to different stakeholders' interests are unlikely to be uniform, and organisational fields are usually characterized by conflicting logics [50-52].

In the context of our research, the market logic and the sustainability logic can be regarded as coexisting but competing logics within the global logistics industry. The stakeholders' demand for a dominant logic and their different approaches to carbon reporting lead to differences in their carbon-disclosure behaviour, because each logic is associated with different organising principles and represents a different set of behaviours from those of stakeholders within the field [17]. In other words, as carbon reporting is embedded in an organisational context, these competing logics at the field level have an impact on the carbon disclosure at the firm level, whether a market or sustainability logic is dominant or whether a mix of both rationales can be found. Moreover, we argue that although the different approaches to carbon disclosure at the firm level-symbolic or substantial—are influenced by legitimisation rationales, the main drivers for the carbon-disclosure behaviour are the underlying competing logics on the field level. In particular, the competition between the market and the sustainability logic leads to either to a pragmatic or a normative perspective within the organisation, which in turn determines either a more symbolic or a more substantial approach to carbon reporting (see Figure 1).

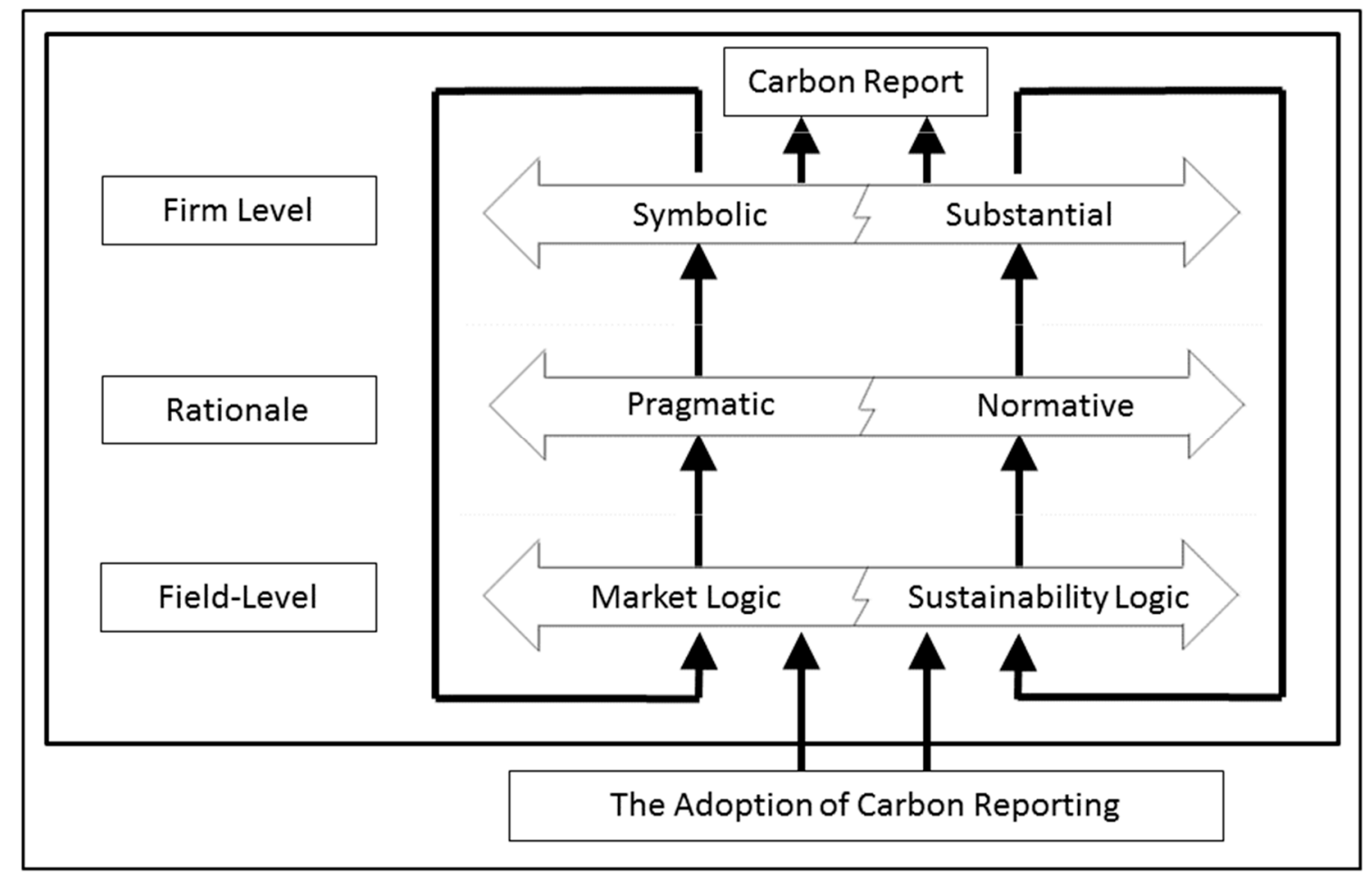

Figure 1. The influence of competing (market vs. sustainability) logics. 
For global logistics companies, a market-driven logic represents the search for sustainability activities that will increase operational efficiencies or reduce carbon emissions to save costs. Schaltegger and Burritt [42] call this behaviour the 'business case' for sustainability-that is, the identification and realization of the economic potential of voluntary environmental activities. It needs to be noted that, in the specific case of logistics companies, the economic factor is the decisive factor for environmental and carbon-reduction engagement [53,54]. Thus, a purely operational efficiency-driven approach with substantial actions, with the main goal being to save costs along with carbon emissions, may not be enough to reflect a legitimacy-driven approach or the sustainability logic. The sustainability logic represents a normative rationale - that is, its orientation goes beyond economic outcomes or arguments, and it requires an additional "assessment of the techniques used to achieve the organisational accomplishments" [13] (p. 180). We argue, therefore, that while the market logic is driven by economic gains, the sustainability logic within the global logistics industry is influenced by legitimacy-driven outcomes that go beyond 'pure' cost savings initiatives.

Another indicator to determine whether companies will follow a market or sustainability logic is what department is responsible to collect, control and communicate the carbon information [17]. A company that sets its public relations and communications department in charge of carbon-related activities is likely to follow a sustainability logic, while aligning carbon-related information with the accounting or finance department indicates a market logic [55-58]. External communication of environmental activities and active engagement in stakeholder dialogues might also represent a legitimacy-driven behaviour, which indicates business transparency and management's commitment to and concern about reducing environmental impact [59]. Moreover, in an engagement with full disclosure of carbon emissions along the supply chain, the degree of transparency might also be indicative of a market or sustainability logic $[1,2]$.

Based on the above discussion, it is not clear yet what drives carbon disclosure behaviour and points to the need to systematically examine which underlying logic-market or sustainability, or a combination of both-dominates carbon disclosure in the global logistics industry. It is argued that the competition between the market and the sustainability logic lead not only to opposing legitimisation approaches, but also lead to differences in the carbon disclosure between DHL, FDX and UPS. Thus, the research aim of this study is to examine whether DHL, FDX and UPS follow a symbolic or substantial measurement and reporting approach and what logic-market or sustainability-dominates the carbon disclosure behaviour of each company.

\section{Research Methods}

To address the research aim of determining the dominant logic that drives the different carbon-disclosure behaviour of DHL, FDX and UPS, the similarities and differences in the carbon-related information of the companies were analysed. In particular, we adopted an interpretative content analysis approach of the statements and declarations of DHL, FDX and UPS in their reports of the Carbon Disclosure Project (CDP). CDP is a prominent international collaboration that works together with more than 3000 of the largest corporations to provide information relevant to investors relating a wide range of climate-related activities, including measurement of emissions, organisational structure, initiatives and engagement, and trading and offsets [24]. The CDP reports were chosen because the information provided has been completed by the company's management, hence it negates research bias in the collection phase. The information provided in these reports is extensive and reflects a company's values and attitudes towards carbon disclosure. Consequently, they provide a good example that not only reveals and highlights the similarities and differences in the statements, but also give an indication of the rationale behind disclosure decisions.

Adopting interpretative content analysis provides in-depth insights into the reporting behaviour of the companies and enables a discussion of the underlying logic behind it. It is, therefore, not a quantitative comparison of carbon emissions, goals and achievements. Rather, interpretative analysis captures meaning by disaggregating narrative into its constituent parts and then describing the contents 
of each disaggregated component $[60,61]$. The capture of the actual content of narrative is important when researchers are interested in understanding disclosure practice [62]. Thus, interpretative studies aim to gain a greater understanding of what is communicated and how meaning is understood [63]. They are therefore concerned with the quality, richness or qualitative character of the narrative. In other words, interpretative analysis is the contextualization of communication, and seeks to reveal the meanings and motivations behind statements in corporate reporting and in this case, what logic drives DHL, FDX and UPS to follow either a symbolic or substantial disclosure approach.

Membership of the CDP was obtained to gain access and obtain the carbon information that the companies provided to stakeholders and investors. CDP reports are regularly published on an annual basis and all available reports from DHL, FDX and UPS were accessed and analysed. All companies provided information for the timeframe 2010-2015, with the exception of UPS, which also published CDP reports in 2008 and 2009. However, the information provided for 2008 and 2009 was rather marginal, thus this study focuses on the reports from 2010 to 2015 where comparisons are possible.

To assess the similarities and differences as well as the logic behind the disclosure behaviour, measures of specific disclosures related to issues associated with carbon-related information are needed. Following the structure of the CDP reports, this study focuses on four categories: (1) the company's carbon strategy; (2) the extent of carbon information provided (the degree of transparency); (3) internal initiatives; and (4) external stakeholder engagement (see Table 1).

Table 1. Carbon disclosure categories. Source: Adapted from Hrasky [13] (p. 184).

\begin{tabular}{lll}
\hline Reporting Type & Description & Analysis \\
\hline $\begin{array}{l}\text { Carbon } \\
\text { Strategy/Climate }\end{array}$ & $\begin{array}{l}\text { Statements indicating the intention of } \\
\text { the carbon strategy, the motivation, } \\
\text { commitment and recognition of the } \\
\text { importance of carbon footprints, global } \\
\text { warming and climate change }\end{array}$ & $\begin{array}{l}\text { Review and analysis of the } \\
\text { carbon/climate change statements and } \\
\text { the organisational structure with regard } \\
\text { to the company's strategic positioning } \\
\text { and logic of carbon-related activities }\end{array}$ \\
\hline $\begin{array}{l}\text { Degree of } \\
\text { Transparency }\end{array}$ & $\begin{array}{l}\text { The extent and details as well as the } \\
\text { approach and development of carbon } \\
\text { information provided in the reports }\end{array}$ & $\begin{array}{l}\text { Review and analysis of the transparency } \\
\text { of carbon information provided with a } \\
\text { focus on exemplary behaviour of } \\
\text { measurement and reporting of Scope 1,2 } \\
\text { and 3 emissions as well as the verification } \\
\text { of the carbon data }\end{array}$ \\
\hline $\begin{array}{l}\text { Internal Initiatives } \\
\text { Stakeholder }\end{array}$ & $\begin{array}{l}\text { Statements about specific internal } \\
\text { corporate actions taken relevant to } \\
\text { carbon footprints, global warming and } \\
\text { climate change }\end{array}$ & $\begin{array}{l}\text { Review and analysis of the internal } \\
\text { carbon-related initiatives and that have a } \\
\text { direct impact on the reduction of the } \\
\text { company's carbon footprint }\end{array}$ \\
\hline $\begin{array}{l}\text { Statements of the companies' external } \\
\text { stakeholder engagement in activities } \\
\text { relevant to carbon footprints, global } \\
\text { warming and climate change }\end{array}$ & $\begin{array}{l}\text { Review and analysis of companies' } \\
\text { external engagement with multiple } \\
\text { stakeholders and their influence of } \\
\text { carbon-related activities }\end{array}$ \\
\hline
\end{tabular}

The first category investigates the company's carbon strategy-that is, how carbon management is integrated into the company's strategy and how climate change risks and opportunities are assessed. It consists of two sub-categories. The first is an indicator to analyse whether the commitment and the climate change strategy are corporate climate change statements. From an organisational perspective, corporate statements can be related to the concept of the institutional statement, which Crawford and Ostrom [64] (p. 583) describe as "a shared linguistic constraint or opportunity that prescribes, permits, or advises actions or outcomes for actors (both individual and corporate)". Hence climate-change statements within a corporate report can be regarded as a reflection of the corporate strategy and a call for action through the introduction or implementation of an organisational practice. Following Criado-Jiménez, et al. [65], the unit of analysis was key sentences that might be reflective of a symbolic or substantial disclosure approach and underpin the logic behind the strategy. Consequently, 
the climate-change statements from DHL, FDX and UPS in the CDP reports from 2010 to 2015 were analysed to highlight the key messages. We expected that these key messages would not only highlight the differences in the corporate statements, but would also provide an indication of the intention, and thus the rationale behind the decision, to engage in carbon-related activities.

Schaltegger and Hörisch [17] examine how carbon management is integrated into the organisational structure as an additional indicator to determine the rationale or logic behind carbon disclosure. If the market logic dominates, we can expect finance or accounting to be important internal actors assessing and deciding on carbon projects and measures [66], whereas if the sustainability logic dominates, the legal and public relations departments are likely to be the important internal forces promoting carbon disclosure [67]. Thus, as a second sub-category, this article will analyse what department in the organisation is dealing with carbon-related activities to ensure that either the carbon strategy or, more generally, the intended direction in carbon management implementation is effectively pursued.

The second category deals with the degree of transparency of the provided carbon information. To investigate the degree of transparency, this article focuses on three points in the timeframe of 2010 to 2015: (1) the extent of Scope 1, 2 and 3 reporting; (2) the verification of data through third parties; and (3) the measurement and control approach. With regard to the extent of Scope emissions, it will be assessed whether Scope 1, 2 and 3 emissions are reported and what level of detailed carbon information is available-particularly for the reporting of Scope 3 emissions. For global logistics companies, purchased transportation by air, rail, road and ocean accounts for the largest source of Scope 3 emissions, and the level of detail of Scope 3 emissions may be an indicator for transparency efforts [24]. Another indicator of transparency is the verification of carbon data through third-party providers, such as accountants and consultancy firms. Finally, we assess the measurement and control approach of DHL, FDX and UPS. Based on The Greenhouse Gas Protocol: A Corporate Accounting and Reporting Standard (Revised Edition), companies can choose different carbon measurement and reporting schemes for their carbon emissions [27]. These different schemes provide guidelines to set boundaries for carbon emissions reporting, and companies can choose between two different control approaches, namely either 'financial' control or 'operational' control. The choice of approach changes how carbon emissions are categorised, which therefore not only influences the amount of carbon emissions to be reported, but may also indicate the level of transparency [68].

The third category investigates the internal initiatives to lighten the corporate carbon footprint, as internal activities are an indicator of symbolic or substantial behaviour [13]. We analyse the development of carbon-related initiatives over the timeframe 2010-2015 in order to understand whether these initiatives have a more symbolic character or are actually reducing the carbon footprint, hence showing substantial behaviour. Another indicator to investigate the influence of the logic or rationale within the respective companies is the comparison of similar initiatives over the timeframe from 2010 to 2015 . While a first-mover initiative may signal normative and exemplary behaviour, the adoption of a similar initiative at a later stage may indicate isomorphic behaviour [69].

The fourth category deals with the external stakeholder engagement of DHL, FDX and UPS. In particular, this category investigates the extent to which the respective companies engage in public policy climate-change activities, such as engagement with policy makers and board membership in business associations, or whether research organisations are funded. We analyse the engagement of DHL, FDX and UPS with regard to their legislation focus, geographical area and partnering with international organisations.

\section{Results and Discussion}

The results show significant variances between the carbon reports of DHL, FDX and UPS. Based on the categories in Table 1, we analysed the content of CDP reports to reveal the meaning behind the information and corporate statements of DHL, FDX and UPS in the context of their carbon reporting, measurement and engagement. 


\subsection{Carbon Strategy/Climate Change Statements}

The findings of the carbon strategy of DHL, FDX and UPS and their related statements comprise two outcomes. First, we analysed the corporate statements and focused on the key messages that contained reflections about the corporate strategy. An analysis of statements provides insight into the range of different key messages and indicates the logic that dominates the carbon strategy. On one end of the spectrum is the market logic — that is, statements that focus on economic benefits, representing a profit-seeking view. At the other end is the sustainability logic-that is, statements that foster transparency or highlighting collaborations, representing a legitimacy-seeking view. Second, we examine the position of department that manages the organisation's carbon-management or sustainability structure. The outcome determines the level of authority and, in turn, indicates the logic behind the carbon disclosure.

We analysed the corporate strategy statements from all three companies on an annual basis from 2010 to 2015 (see Table 2). A corporate statement not only specifies the purpose and the set of institutional rules, but also indicates whether the statement must, must not, or may be followed [64]. Moreover, corporate statements change over time, as does the demand for or prohibition on a particular behaviour, which may lead to heterogeneity in disclosure practices within companies. The analysis shows that the three companies changed their statements at different stages, which is reflected in the different key messages about the carbon strategy in the CDP reports of DHL, FDX and UPS.

The corporate strategy statements of the early CDP reports of all three companies are mainly related to improving operational efficiency and fuel savings, stating to "optimise the processes that consume non-renewable resources" (UPS) [70] (p. 10), "carbon efficiency is ... directly related to ... cost efficiency" (DHL) [71] (p. 3) and to undertake (environmental) initiatives for business reasons" (FDX) [72] (p. 5). These statements focus on the economic benefits of sustainability activities and are referred to by Schaltegger and Burritt [42] as the 'business case' for sustainability, indicating a focus on a market logic-driven perspective. However, all three companies changed their strategic climate change statements. UPS changed its statement in 2011, and DHL and FDX made major changes in 2013; the statements of the three companies did not change again up until 2015. This finding reveals that all three companies did appear to be responding to societal changes at different stages. The time pattern observed suggests that UPS was the first company to shift away from a rather market-logic driven perspective towards a sustainability logic, followed by DHL and FDX in 2013.

One indication of the integration of the sustainability logic is the key messages that integrate customers and suppliers. Hoffman [73] analyses corporate strategies for addressing climate change and notes that an integration of suppliers and customers is an important component of a successful climate-management strategy. In the updated corporate statements, DHL and UPS changed their key message accordingly, stating that "customers will depend on UPS's transparency" [74] (p. 6) and that the aim is to "share ... expertise ... with our customer" (DHL) [75] (p. 3). Moreover, a focus on Scope 3 emissions in also included as a key message of DHL, with the company claiming to "improve efficiency including both own and subcontract operations" [76] (p. 3). UPS's message is to "advocate full disclosure (Scope 1, 2 and 3)" [77] (p. 6). According to Suddaby and Greenwood [47], the development of a statement can build legitimacy if it includes institutional vocabulary that articulates the rationale behind an organisational practice and language that reflects the pace and the necessity of change within the field. Following that argument, although DHL and UPS both still include the market logic in their statements-UPS: "focus on avoiding and reducing energy use and emissions" [74] (p. 6); DHL: "[the] main aspect ... is the carbon efficiency of its operations" [76] (p. 3) -the inclusion of messages beyond economic benefits indicates a transition or the provision of greater attention to legitimacy-driven statements. As such, DHL and UPS are in line with the findings of Bouteligier [78] that companies integrate environmental values into their corporate strategies. 
Table 2. Carbon strategy statements.

\begin{tabular}{|c|c|c|c|c|c|}
\hline \multicolumn{6}{|c|}{ Carbon Strategy_Statements } \\
\hline Year(s) & DHL & Year(s) & $F D X$ & Year(s) & UPS \\
\hline 2015-2013 & $\begin{array}{l}\text { "... main aspect for a global logistics } \\
\text { provider }(\ldots) \text { is the carbon efficiency } \\
\text { of its operations" /"Our long-term } \\
\text { strategy is influenced by }(\ldots .) \\
\text { 'Shared Value' approach ... " "We } \\
\text { share }(\ldots) \text { expertise with our } \\
\text { customers, }(\ldots) \text { helping them } \\
\text { minimize the environmental impact } \\
\text { of their business activities." /“... } \\
\text { improve efficiency (against target) } \\
\text { including both own and subcontract } \\
\text { operations" /“ ... growing influences } \\
\text { in regulatory changes ..." /“... we } \\
\text { address key risk factor }(\ldots) \text { : } \\
\text { potential pricing scenarios for GHG." }\end{array}$ & 2015-2013 & $\begin{array}{l}\text { "... Our short-term business strategy } \\
\text { is heavily influenced by the } \\
\text { longer-term goals }(\ldots .) \text { around } \\
\text { aircraft emissions intensity and } \\
\text { vehicle fuel efficiency ..." "/.... } \\
\text { manage their environmental } \\
\text { performance in line with business } \\
\text { needs" } / . . . \text { fuel efficiency and } \\
\text { alternative energy development } \\
\text { should put us in in a position to take } \\
\text { (strategic) advantage of any } \\
\text { significant opportunities associated } \\
\text { with climate change ..." ".... } \\
\text { GHGs emitted by companies in the } \\
\text { airline and transportation industry } \\
\text { could harm our reputation ... }\end{array}$ & 2015-2011 & 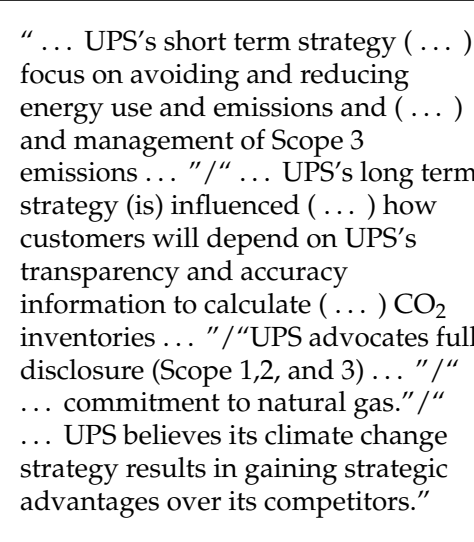 \\
\hline \multirow{2}{*}{ 2012-2010 } & \multirow{2}{*}{$\begin{array}{l}\text { "... GoGreen is the core of our } \\
\text { Climate Strategy is key constituent of } \\
\text { our Corporate Strategy ..." /. ... } \\
\text { Carbon efficiency is of strategic } \\
\text { importance, since our carbon } \\
\text { emissions are directly related to our } \\
\text { fuel and energy consumptions and } \\
\text { thus to cost efficiency." }\end{array}$} & 2012 & $\begin{array}{l}\text { "... main responsibility to create and } \\
\text { sustain long-term stockholder } \\
\text { value." /.... we undertake } \\
\text { (environmental) initiatives for } \\
\text { business reasons." }\end{array}$ & \multirow{2}{*}{2010} & \multirow{2}{*}{$\begin{array}{l}\text { "Our long-term strategy is to optimize } \\
\text { the processes that consume } \\
\text { non-renewable resources." / ... UPS } \\
\text { is a critical component of our } \\
\text { customers' supply chains, and we } \\
\text { have an obligation to help them } \\
\text { operate in a more environmentally } \\
\text { sustainable way ..." }\end{array}$} \\
\hline & & 2011-2010 & $\begin{array}{l}\text { "... continue to look at and identify } \\
\text { our areas of exposure with regard to } \\
\text { greenhouse gas emissions." /“... } \\
\text { determine the level of potential } \\
\text { impact..." /. ... set appropriate plans, } \\
\text { including goals ..." "/... monitor } \\
\text { progress ..." }\end{array}$ & & \\
\hline
\end{tabular}


In contrast, FDX does not address full disclosure of Scope 3 emissions or its suppliers' transparency issues, but rather includes general forward-looking statements such as that "GHGs emitted by companies in the airline and transportation industry could harm our reputation" [32] (p. 4). This statement highlights a potential legitimacy gap for FDX as the result of a change in social values due to the evolving environmental consciousness in society about climate change, but does not indicate legitimacy-driven actions to close the gap. Thus, the ongoing lack of legitimacy-driven statements in the climate-change strategy of FDX may indicate a potential breach of the 'social contract', where corporate performance remains largely unchanged, but social expectations about performance have evolved [79]. Moreover, FDX delegates corporate action to all operating companies to 'manage their environmental performance in line with business needs' [32], which indicates a stronger focus on the market logic compared with DHL and UPS. In other words, while FDX appears to have reacted to changed social pressures with a direct 'business case' response, DHL and UPS seem to have offered an indirect legitimation response that further integrates the stakeholders' perceptions that are maintaining the social contract.

Differences can also be observed in the three companies' organisational structures and how carbon reporting in the broader context of sustainability is integrated into each company's strategy. UPS had appointed a Chief Sustainability Officer (CSO), who was responsible for the industry leadership of sustainable business practices, transparency and meeting the company's emissions-reduction goals. UPS's CSO had a direct reporting line to the SVP of Global Engineering and Sustainability, a member of the UPS Management Committee [34]. A direct reporting line to an engineering department may indicate a focus on operational issues, and hence substantial measures to reduce carbon emissions. In contrast, the sustainability or carbon management at DHL had a direct reporting line to the public relations department [80]. The responsible person for sustainability management at DHL was the head of the Corporate Communications and Responsibility Department, who discussed environmental projects on a bi-weekly basis with the CEO of DHL. According to Schaltegger and Hörisch [17], the integration of sustainability or carbon management into the public relations department indicates a legitimacy-driven behaviour. FDX follows a different approach, as it delegates the management of environmental performance to the operating companies and has implemented Sustainability Impact Teams (SITs), which report to the FedEx Enterprise Sustainability Council (FESC), chaired by the Vice President for Environmental Affairs and Sustainability. Interestingly, FDX does not disclose its direct reporting line or which level of authority is given to the FESC [34].

The corporate strategy statements of all three companies, as well as the organisational structure behind carbon disclosure, provide a clear indication of the rationale behind their carbon reporting. If climate-change statements and carbon-related activities are designed in a way that will, or is likely to, increase profits, the company is likely to follow a profit-seeking rationale or the market logic [17]. In contrast, an engagement from UPS that "advocates full disclosure" [77] (p. 6) or DHL's rhetorical strategy to implement a "shared value" approach [76] (p. 3) indicates that carbon-related activities are designed to secure legitimacy. The analysis indicates that the three companies are committed to reduce their carbon emissions output, but are following different strategies. While FDX emphasizes a more profit-seeking behaviour of sustainability in its statement, DHL and UPS emphasize the legitimacy perspective to gain a competitive advantage over other competitors.

\subsection{Degree of Transparency}

The analysis of the degree of transparency consists of three points: (1) the extent of Scope 1, 2 and 3 reporting; (2) the verification of data through third parties; and (3) the measurement and control approach. Between 2010 and 2015, the analysis of the Scope 1, 2 and 3 emissions and their verification shows similarities between DHL and UPS, but differences for FDX (see Table 3). While all companies reported emissions in all categories, we found differences in the geographical boundaries and in the verification of carbon data. In 2010, DHL and UPS reported Scope 1 and 2 emissions on a global basis, while the FDX data was restricted to the United States. Moreover, no company had third-party 
verification of its data at that time $[70,81,82]$. While DHL and UPS provided verified data for Scope 1 and 2 emissions for their global operations as of 2011, FDX lacked verification of Scope 1 emissions until 2014 and had not verified Scope 2 emissions in 2015 [32,34,80].

Table 3. Scope emissions reporting. Legend: $\rightarrow=3$ rd party verified; grey = not verified by 3rd party. US only: reporting of emissions restricted to the US only. US\&CA: reporting of emissions restricted to US and Canada only.

\begin{tabular}{|c|c|c|c|c|c|c|c|c|c|}
\hline \multirow[t]{2}{*}{ Year } & \multicolumn{3}{|c|}{ Scope 1} & \multicolumn{3}{|c|}{ Scope 2} & \multicolumn{3}{|c|}{ Scope 3} \\
\hline & $\overline{D H L}$ & $F D X$ & UPS & $\overline{D H L}$ & $F D X$ & UPS & DHL & $F D X$ & UPS \\
\hline 2015 & & & & & & & & (USECA) & \\
\hline 2014 & & & & & & & & (USECA) & \\
\hline 2013 & & & & & & & & (US only) & \\
\hline 2012 & & & & & & & & (US only) & \\
\hline 2011 & & & & & & & & (US only) & \\
\hline 2010 & & (US only) & & & (US only) & & & (USECA) & \\
\hline
\end{tabular}

Another important point is the reporting of Scope 3 emissions within the global logistics industry. As all companies use partners worldwide for pick-up and delivery services, purchased transportation by air, rail, road and ocean accounts for the largest source of Scope 3 emissions at DHL, FDX and UPS [29,30,75]. However, as subcontractors usually do not disclose information on fuel burn, scope 3 emissions are based largely on complex calculation models and scenarios, taking into account data from operational systems such as origins, destinations and routing, and may be an indicator of the extent to which DHL, FDX and UPS provide transparency in their Scope 3 emissions.

Based on the data from the CDP reports, only DHL and UPS seemed to report their full Scope 3 emissions from purchased transportation [34,80]. FDX acknowledged the relevance of this data, but did not seem able to calculate relevant data. Its reporting of carbon emissions related to pick-up and delivery services was limited to the freight subdivision in the United States and Canada, and the feeder aircraft contractors, but was not available from pick-up and delivery subcontractors outside the United States and Canada [32]. Moreover, the Scope 3 emissions of DHL and UPS were verified by an independent auditor, while FDX had verification only for Scope 1 emissions [83]. Moreover, UPS reported for four of the seven greenhouse gases covered by the Kyoto Protocol, including a table with a conversion rate of 'Global Warming potential', while DHL and FDX only reported for three greenhouse gases.

The measurement and control approach may also be an indication of transparency and the rationale behind carbon disclosure. Within the Greenhouse Gas Protocol: A Corporate Accounting and Reporting Standard (Revised Edition), companies can choose different carbon measurement and reporting schemes for their carbon emissions [27]. These different schemes provide guidelines for setting boundaries for carbon emissions reporting. As discussed previously, companies can choose between two different control approaches: 'financial' control or 'operational' control. In both wholly owned and joint operations, the choice of approach changes how carbon emissions are categorised when operational boundaries are set, and therefore influence the amount of carbon emissions to be reported [27].

Therefore, to measure carbon emissions, DHL, FDX and UPS were able to set different organisational boundaries-that is, they could follow different 'control' approaches to measure carbon emissions. While DHL and FDX followed the financial approach, UPS applied the operational approach. In the financial approach, companies need only to report emissions from ventures in which they hold more than a 50 per cent interest [27]. In other words, DHL and FDX did not need to report carbon from partnerships and cooperation for pick-up and delivery services if they did not own more than 50 per cent of the partner company. Compared with that of UPS, 'this approach may lead to less complete reporting', because when an operational control is applied, the carbon measurement and reporting are "not limited to majority-held ventures, [but] also [apply] to minority ventures" [68] (pp. 3-5). Thus, 
an operational approach can be regarded as a more complete and transparent approach, as it tries to capture emissions from the entire operational network.

Overall, with regard to transparency, it seems that UPS showed the most exemplary and transparent behaviour, closely followed by DHL. Both DHL and UPS reported their verified Scope 1, 2 and 3 emissions fully, while FDX showed a rather mimetic behaviour as it verified only Scope 1 emissions and did not seem able to fully disclose Scope 3 emissions. According to Hopwood [16] (p. 437), the full disclosure, as performed by DHL and UPS, is a clear indication of enhanced transparency of environmental activities, and represents a substantial behaviour of companies. He argues further that the lack of available transparent data may 'thicken the corporate veil', and may indicate a rather symbolic management approach aimed at achieving pragmatic legitimacy. Moreover, the data suggest that DHL and UPS had started to integrate carbon measurements into their strategy at an earlier stage, which could explain the more detailed and comprehensive availability of the carbon data of DHL and UPS, as well as the more transparent information provided to stakeholders. However, the application of the 'operational' control approach and the higher number of reported greenhouse gases tends to support more transparent behaviour and a more complete reporting approach of UPS over DHL and FDX.

\subsection{Internal Initiatives}

The commitment to reduce the carbon footprint within the operational network is also reflected in the internal activities of DHL, FDX and UPS. It needs to be emphasized that the internal activities in both companies were related mainly to operational excellence (see Table 4). In other words, most carbon footprint reductions are directly linked to improving operational efficiency and fuel savings. Both companies divided their initiatives into an aircraft and a vehicle segment. To reduce aircraft emissions, which represent almost 80 per cent of all transportation fleet emissions, FDX established a 'Fuel Sense' program, which included algorithms to better predict fuel consumption for departure and arrival of planes as well as to reduce weight during the flight [72]. UPS internal activities included the instalment of 'Winglets' to reduce fuel consumption and DHL implemented a 'GoGreen' initiative to drive behavioural change [32]. For the transportation fleet, FDX developed a program called 'Reduce, Replace and Revolutionize' to improve vehicle efficiency, which mainly focused on optimizing routes and the use of electric vehicles. In comparison, UPS focused on the implementation of an alternative fuel fleet, which included LNG tractors and the building of related infrastructure in the form of LNG fuelling stations [34]. DHL also focused on the deployment of electric or dual-fuel vehicles, and replaced vans with bikes in the main urban areas. All these internal activities from the three companies were voluntary initiatives that reduced the carbon footprint. However, although these substantial activities indicate that carbon disclosure mirrors action, it may not result in real changes within the organisation and may create a façade that is fashioned to "thicken the veil and reduce scrutiny" [84] (p. 375). In a similar vein, in his analysis of corporate climate change strategy, Hoffman [73] (p. 16) notes a tendency to pick the "low-hanging" fruit by reporting easily identified low-cost and/or low-risk actions without really embracing ongoing organisational adaption strategies to mitigate climate change.

Thus, an analysis of the specific similar initiatives that are not related to energy efficiency may indicate exemplary behaviour or a legitimacy-seeking approach within the industry. One example might be the carbon-neutral envelope initiative. The carbon-neutral service for envelopes was introduced by DHL in 2007 and UPS in 2009, while FDX implemented the service in 2012 [70,72,81]. Another initiative that is not related to operational excellence is the introduction of a carbon emissions tracker tool for customers. While DHL introduced a carbon tracker tool for customers in 2010, UPS and FDX followed suit in 2013. Thus, time differences in the implementation of non-efficiency driven initiatives can be observed, with DHL claiming the first-mover advantage. However, it is evident that DHL, FDX and UPS have implemented substantial activities to reduce carbon emissions that indicate the opposite of symbolic reporting behaviour. 
Table 4. Main internal initiatives.

\begin{tabular}{|c|c|c|c|}
\hline & \multicolumn{3}{|c|}{ Main Internal Initiatives } \\
\hline Year & $D H L$ & $F D X$ & UPS \\
\hline 2015 & $\begin{array}{l}\text { Expand on road fleet } \\
\text { aerodynamic deployment } \\
\text { Expand on replacing vehicles } \\
\text { with bikes in urban areas } \\
\text { - Introducing solar charging } \\
\text { station for electric DHL scooters } \\
\text { in Taiwan }\end{array}$ & $\begin{array}{ll}\text { - } & \text { Testing/Developing } \\
\text { - } & \text { Alternative Jet Fuel } \\
\text { Expand Fuel Sense (Aircraft } \\
\text { Taxi Fuel Reduction) } \\
\text { - } \quad \text { Expand on hybrid/electric } \\
\text { vehicles \& alternative fuels }\end{array}$ & $\begin{array}{ll}\text { - } & \text { Aircraft Modification } \\
\text { (Installation of Winglets) } \\
\text { - } & \text { Expand on hybrid/electric } \\
\text { vehicles \& alternative fuels }\end{array}$ \\
\hline 2014 & $\begin{array}{l}\text { - } \quad \text { Replace entire fuel delivery } \\
\text { vehicles with electric vehicles in } \\
\text { one city (Bonn, Germany) } \\
\text { Replace vehicles with bikes in } \\
\text { urban areas (Netherlands, } \\
\text { Greece, Luxembourg, Austria, } \\
\text { UK, Croatia) }\end{array}$ & $\begin{array}{ll}- & \text { Aircraft replacements } \\
- & \text { Intermodal (Truck to Train) } \\
\text { - } & \text { Trailer Fuel Efficiency } \\
\text { (aerodynamics) } \\
\text { - } & \begin{array}{l}\text { Expand on Energy Efficiency } \\
\text { (Fuel Sense, Solar) }\end{array}\end{array}$ & $\begin{array}{l}\text { - Intermodal Transport (Air } \\
\text { to Ground) } \\
\text { Expand on route } \\
\text { optimization technologies }\end{array}$ \\
\hline 2013 & $\begin{array}{ll}\text { - } & \text { Road fleet } \\
\text { aerodynamic deployment } \\
\text { - } & \text { Introduction of dual fuel } \\
\text { vehicles (Diesel \& LNG) }\end{array}$ & $\begin{array}{ll}\text { - } & \text { Customer Carbon } \\
& \text { Reporting Tool } \\
\text { - } & \text { Drivers Coaching } \\
\text { - } & \text { Behavioral Change (work } \\
& \text { from home program) }\end{array}$ & $\begin{array}{ll}\text { - } & \text { Customer Carbon } \\
\text { Reporting Tool } \\
\text { - } \quad \text { Expand Telematics to } \\
\text { Latin America \& Europe } \\
\text { (Idle time and } \\
\text { miles reduction) } \\
\text { - Drivers Coaching }\end{array}$ \\
\hline 2012 & $\begin{array}{l}\text { Expand on Fuel Savings (Driver } \\
\text { Training with own } \\
\text { and subcontractors) } \\
\text { Behavioral Change } \\
\text { (GoGreen initiative) }\end{array}$ & $\begin{array}{ll}\text { - } & \text { Introduction of Carbon } \\
\text { Neutral Service } \\
\text { - Vehicle } \\
\text { Replacements/Hybrids \& } \\
\text { EV deployment }\end{array}$ & - $\quad$ Solar installations (US) \\
\hline 2011 & $\begin{array}{l}\text { - Test of aerodynamics devices for } \\
\text { subcontractors (Poland) } \\
\text { - Energy Efficiency } \\
\text { (LED-Germany) }\end{array}$ & $\begin{array}{l}\text { - } \quad \text { LEED within FedEx Express } \\
\text { (Energy Efficiency) }\end{array}$ & $\begin{array}{l}\text { - Expand Package Flow } \\
\text { Technology Introducing } \\
\text { LNG vehicles } \\
\text { - Intermodal Transport (Air } \\
\text { to Ground/Ground } \\
\text { to Rail) }\end{array}$ \\
\hline 2010 & $\begin{array}{ll}\text { - } & \text { Introduction of electric vehicles } \\
\text { - } & \text { Fuel Savings (Routing } \\
\text { Optimization, } \\
\text { - } & \text { Vehicle Modifications) } \\
\text { - } & \text { Aircraft Replacement } \\
\text { Customer Carbon } \\
\text { - } \quad \text { Reporting Tool } \\
\text { Carbon Neutral Service } \\
\text { (Envelope/from 2007) }\end{array}$ & $\begin{array}{ll}\text { - } & \text { Fuel Sense (Aircraft } \\
\text { Fuel Optimization) } \\
\text { - } \quad \text { Reduce, Replace, } \\
\text { Revolutionize (Vehicle } \\
\text { Routing Optimization, } \\
\text { Electric Vehicles) } \\
\text { - Solar Installations }\end{array}$ & $\begin{array}{ll}\text { - } & \text { Package Flow Technology } \\
\text { (Routing-US) } \\
\text { Telematics (US-Idle time } \\
\text { and miles reduction) } \\
\text { - } \quad \text { Carbon Neutral Service } \\
\text { (Envelope/from 2009) }\end{array}$ \\
\hline
\end{tabular}

\subsection{External Stakeholder Engagement}

Active external stakeholder engagement is an indicator of management's commitment to reduce the environmental impact [59]. In the case of DHL, FDX and UPS, all three companies engaged in public policy climate-change activities and worked directly with policy makers as well as funding research organisations. However, only FDX and UPS worked actively with, or were board members of, trade organisations, while DHL did not list such an engagement (see Table 5). 
Table 5. External stakeholder engagement.

\begin{tabular}{|c|c|c|c|}
\hline & \multicolumn{3}{|c|}{ Main Stakeholder Engagement } \\
\hline Engagement Categories & DHL & $F D X$ & UPS \\
\hline $\begin{array}{l}\text { Public Policy Climate } \\
\text { Change Activities }\end{array}$ & $\begin{array}{l}\text { - } \quad \text { Direct Engagement with policy makers } \\
\text { - } \quad \text { Funding research organizations }\end{array}$ & $\begin{array}{ll}\text { - } & \text { Direct Engagement with policy makers } \\
\text { - } & \text { Trade Associations } \\
\text { - } & \text { Funding research organizations }\end{array}$ & $\begin{array}{ll}\text { - } & \text { Direct Engagement with policy makers } \\
\text { - } & \text { Trade Associations } \\
\text { - } & \text { Funding research organizations }\end{array}$ \\
\hline Legislation focus & $\begin{array}{ll}\text { - } & \text { Cap and Trade (ETS)/EU } \\
\text { - } \quad \text { Mandatory Carbon reporting/France } \\
\text { - }\end{array}$ & $\begin{array}{ll}\text { - } & \text { Reduced GHG emissions and increased fuel } \\
\text { efficiency/US } \\
\text { - } & \text { Carbon pricing/Global }\end{array}$ & $\begin{array}{ll}- & \text { Mandatory Carbon reporting/US } \\
-\quad & \text { Energy efficiency/US and Germany } \\
\text { - } & \text { Clean energy generation/US and EU }\end{array}$ \\
\hline Stakeholders involved & - Global Logistics Emissions Council & $\begin{array}{ll}- & \text { SAFE (Securing America's Future Energy)/US } \\
\text { - } & \text { Environmental Protection Agency (EPA) and } \\
\text { - } & \text { EPA SmartWay Transport Partnership/US } \\
\text { Commission for Environmental Cooperation } \\
\text { (CEC)/NAFTA }\end{array}$ & $\begin{array}{ll}- & \text { Department of Energy (DOE) } \\
\text { International Civil Aviation } \\
\text { Organization (ICAO) }\end{array}$ \\
\hline $\begin{array}{l}\text { Board Membership and } \\
\text { Funding of Trade Associations }\end{array}$ & - $\quad$ No & - $\quad$ Yes & - $\quad$ Yes \\
\hline $\begin{array}{l}\text { Trade Associations } \\
\text { Board Membership }\end{array}$ & - & $\begin{array}{ll}- & \text { Airlines for America (A4A)/US } \\
- & \text { American Trucking Association (ATA)/US } \\
\text { - } & \text { Energy Security Leadership Council (ESLC/Part } \\
& \text { of SAFE)/US } \\
\text { - } & \text { Electrification Coalition/US }\end{array}$ & $\begin{array}{ll}\text { - } & \text { Electric Drive Transportation Association } \\
& \text { (EDTA)/US } \\
\text { - } & \text { Natural Gas Vehicles of America (NGV)/US } \\
\text { - } & \text { US Chamber of Commerce/US } \\
\text { - } & \text { Airlines for America (A4A)/US }\end{array}$ \\
\hline $\begin{array}{l}\text { Other Stakeholders } \\
\text { Membership }\end{array}$ & $\begin{array}{ll}\text { - } & \text { Green Freight Europe (GFE)/Belgium } \\
\text { - } & \text { Green Freight Asia (GFA)/Singapore } \\
\text { - } & \text { GEF's Climate CEOs Initiative }\end{array}$ & $\begin{array}{ll}\text { - } & \text { Commercial Aviation Alternative Fuels } \\
\text { - } & \text { Initiative (CAAFI) } \\
\text { American Society for Testing and } \\
\text { Materials (ASTM) } \\
\text { - } \quad \text { EMBARQ/WRI (Center for } \\
\text { Sustainable Transport) } \\
\text { - Yale Center for Environmental Law }\end{array}$ & - Green Freight Asia (GFA)/Singapore \\
\hline
\end{tabular}


The direct engagement of all three companies with policy makers focused on climate change legislation, and was related mainly to the main market of the respective companies, with the United States for FDX and UPS, and Europe for DHL. While DHL was involved in the Emission Trading Scheme (ETS) Cap and Trade system, FDX and UPS focused on fuel efficiency and clean energy generation in the US market. The overall legislative focus, however, addresses similar and more global challenges, such as standardized carbon-related measurement systems and energy efficiency standards. Based on the data of the CDP reports, DHL worked with the 'Global Logistics Emissions Council', while FDX and UPS seemed to be strongly involved with government agencies to lobby for these standards. FDX appeared to work closely with the Environmental Protection Agency (EPA) on greenhouse gas standards, while UPS listed the Department of Energy (DOE) and lobbied for dual-fuel engines in trucks.

Moreover, FDX and UPS were working with trade associations to address carbon-related activities. Both companies worked with non-profit organisations towards achieving a shift from fossil fuels to electric transportation, and both were members of the Airlines for America (A4A) association, which advocates a carbon-neutral approach and an 'aggressive set of measures and emission targets' under the UN-led International Civil Aviation Organisation (ICAO). The FDX chairman and CEO was also involved in the Securing America's Future Energy (SAFE) committee to stimulate the deployment of hybrid vehicles, while UPS engaged in the Natural Gas Vehicles (NGV) industry to reduce carbon emissions.

Furthermore, all three companies were involved in global non-profit organisations that dealt with carbon-related activities and sustainability. While DHL was part of the WEF's (World Economic Forum) Climate Change CEO Initiative, FDX worked with the WRI (World Resource Institute). DHL and UPS were both members and funding partners of the Green Freight Asia (GFA) and FDX was working with the CAAFI (Commercial Aviation Alternative Fuels Initiative) on biofuels. All these initiatives can be regarded as substantial behaviours, and can be regarded as reflecting an active engagement in working on standards for and the transparency of carbon-related activities in the logistics industry.

\section{Conclusions and Implications for Further Research}

The results provide interesting insights into the carbon-reporting behaviour of DHL, FDX and UPS in the global logistics industry. We found a great degree of variability and inconsistency in what DHL, FDX and UPS reported about their carbon impacts. Although our examination of the four categories showed similarities, it also revealed significant differences between the companies' approach towards carbon disclosure. First, the analysis of the carbon strategy and the climate-change statements over time showed a transition from a tendency towards the market logic in the early CDP reports to the incorporation of legitimacy-seeking statements in more recent years for all three companies. However, DHL and UPS appeared to communicate their strategy intentions and statements differently from FDX. While the communications patterns of DHL and UPS included statements regarding a legitimate and more transparent disclosure approach for customers and suppliers, FDX focused on cost savings through operational excellence and included forward-looking statements. As such, the climate-change statements reveal that the three companies pursued different carbon-related strategies. DHL and UPS paid greater attention to legitimacy-seeking arguments, while FDX focused more on the economic benefits that could be achieved through energy and fuel savings. It needs to be emphasised that both approaches are legitimate strategies to gain a competitive advantage. However, it appears that DHL and UPS focused on gaining a competitive advantage through the greater incorporation of the sustainability logic, whereas FDX seemed to focus more on the market logic.

The analysis of the disclosure behaviour regarding the degree of transparency also showed similar variations between DHL, FDX and UPS. While DHL and UPS fully disclosed Scope 1, 2 and 3 emissions, FDX Scope 3 emissions were limited geographically to North America and the feeder operations. Moreover, FDX was the only company of the three to lack full verification of the carbon data by an independent auditor in 2015. However, although DHL and UPS showed more transparent 
behaviour, a gradual increase in the transparency efforts of FDX from 2010 to 2015 can be observed. From an institutional theory perspective, the transparency efforts of FDX can be attributed to mimetic processes or normative isomorphism that incorporate a stronger focus on the sustainability logic in corporate practices. Similar to the findings within the corporate climate change statements, it seems that DHL and UPS started earlier to integrate carbon-related activities and legitimacy-seeking elements into their corporate strategies.

The analysis of the internal initiatives and the external stakeholder engagement of the three companies did not reveal surprising results or major differences. It seems that all three companies have been actively engaged in reducing carbon emissions in their operations, and all three companies have worked with key stakeholders on carbon-related standards and legislations. They have all implemented extensive initiatives to reduce aircraft emission and improve fuel efficiency in their transportation fleets. Moreover, all companies have started, or have plans, to replace fossil fuel, driven vans with dual-fuel or electric vehicles and invest in biofuels. While the main internal initiatives for operational excellence can be regarded as substantial, it may relate to the 'low-hanging fruit', thus not representing an ongoing organisational climate change adaption strategy.

However, the analysis over time with regard to the early adoption of initiatives reveals differences between the three companies. Again similar to the findings in the climate-change statements and the degree of transparency, FDX introduced specific carbon-related products such as a carbon-neutral envelope service and the carbon tracker for customers after DHL and UPS, again showing isomorphic behaviour. From a stakeholder engagement perspective, all three companies worked actively with policy-makers and government agencies on carbon-related topics. The analysis here suggests that all three companies have adopted similar substantial approaches towards carbon-reduction actions, with minor differences in the implementation of initiatives over time.

The results of the analysis must be interpreted in the light of its limitations. The sample size is very small, with only three cases, and this limits the generalizability of the results. Like all approaches adopting interpretative content analysis, the data analysis is inherently narrative, as it relies on reported information as reflective of corporate actions and intent. In addition, the analysis comprised only CDP reports, and it may be the case that different or more extensive disclosure is made elsewhere. We invite future research in the area of emerging logics and carbon reporting, and their influence on the organisational field. Although DHL, FDX and UPS can be regarded as representing an own industry or an organisational field, we encourage future research to expand the boundaries of this organisational field and apply research in the broader field of global logistics companies. It is, for instance, still unclear if or how different logics or different carbon disclosure practices influence actual carbon emissions or investor's decisions. Carbon disclosure in the global logistics arena is still in its infancy, and as organisations face institutional and regulatory changes, there is a need to understand how these affect organisational practices in the future.

Author Contributions: David M. Herold contributed to the manuscript by providing the initial concept development, data collection and analysis. Ki-Hoon Lee conducted further development of conceptual framework, research design and analysis approach to contribute to this paper. Both authors jointly wrote the paper.

Conflicts of Interest: The authors declare no conflict of interest.

\section{References}

1. Kolk, A.; Levy, D.; Pinkse, J. Corporate responses in an emerging climate regime: The institutionalization and commensuration of carbon disclosure. Eur. Account. Rev. 2008, 17, 719-745. [CrossRef]

2. KPMG. Corporate Sustainability—A Progress Report; KPMG: Amsterdam, The Netherlands, 2014.

3. World Economic Forum. Logistics \& Supply Chain; World Economic Forum: New York, NY, USA, 2012.

4. Hahn, R.; Reimsbach, D.; Schiemann, F. Organizations, climate change, and transparency: Reviewing the literature on carbon disclosure. Organ. Environ. 2015, 28, 80-102. [CrossRef]

5. Brundtland, G.H. Our Common Future: Report of the World Commission on Environment and Development; Oxford University Press: Oxford, UK, 1987; Volume 1, p. 383. 
6. UN. United Nations framework convention on climate change. In Proceedings of the United Nations Framework Convention on Climate Change, New York, NY, USA, 9 May 1992.

7. Evangelista, P.; Huge-Brodin, M.; Isaksson, K.; Sweeney, E. Purchasing green transport and logistics services: Implications from the environmental sustainability attitude of 3pls. In Sustainable Practices: Concepts, Methodologies, Tools, and Applications; Information Resource Management Association: Hershey, PA, USA, 2013; Volume 1, pp. 86-102.

8. Abbasi, M.; Nilsson, F. Developing environmentally sustainable logistics: Exploring themes and challenges from a logistics service providers' perspective. Transport. Res. D Transp. Environ. 2016, 46, 273-283. [CrossRef]

9. Lieb, K.J.; Lieb, R.C. Environmental sustainability in the third-party logistics (3pl) industry. Int. J. Phys. Distrib. Logist. Manag. 2010, 40, 524-533. [CrossRef]

10. Perotti, S.; Zorzini, M.; Cagno, E.; Micheli, G.J. Green supply chain practices and company performance: The case of 3pls in italy. Int. J. Phys. Distrib. Logist. Manag. 2012, 42, 640-672. [CrossRef]

11. Herold, D.M.; Lee, K.-H. Carbon Management in the Logistics and Transportation Sector: An Overview and New Research Directions. 2017. Available online: http://www.tandfonline.com/doi/abs/10.1080/17583004. 2017.1283923 (accessed on 15 March 2017).

12. Gotsi, M.; Wilson, A.M. Corporate reputation: Seeking a definition. Corp. Commun. Int. J. 2001, 6, 24-30. [CrossRef]

13. Hrasky, S. Carbon footprints and legitimation strategies: Symbolism or action? Account. Audit. Account. J. 2011, 25, 174-198. [CrossRef]

14. Kim, J.-N.; Bach, S.B.; Clelland, I.J. Symbolic or behavioral management? Corporate reputation in high-emission industries. Corp. Rep. Rev. 2007, 10, 77-98.

15. Suchman, M.C. Managing legitimacy: Strategic and institutional approaches. Acad. Manag. Rev. 1995, 20, 571-610.

16. Hopwood, A.G. Accounting and the environment. Account. Organ. Soc. 2009, 34, 433-439. [CrossRef]

17. Schaltegger, S.; Hörisch, J. In search of the dominant rationale in sustainability management: Legitimacy-or profit-seeking? J. Bus. Ethics 2015. [CrossRef]

18. Calhoun, C. Nationalism and ethnicity. Annu. Rev. Sociol 1993, 19, 211-239. [CrossRef]

19. Onghena, E.; Meersman, H.; Van de Voorde, E. A translog cost function of the integrated air freight business: The case of fedex and ups. Transport. Res. A 2014, 62, 81-97. [CrossRef]

20. Scott, W.R. Unpacking institutional arguments. In The New Institutionalism in Organizational Analysis; Powell, W.W., DiMaggio, P.J., Eds.; University of Chicago Press: Chicago, IL, USA, 1991; pp. 164-182.

21. Levy, D.L.; Kolk, A. Strategic responses to global climate change: Conflicting pressures on multinationals in the oil industry. Bus. Politcs 2002, 4, 275-300. [CrossRef]

22. Lash, J.; Wellington, F. Competitive advantage on a warming planet. Harv. Bus. Rev. 2007, 85, 95-102.

23. Lee, K.-H.; Vachon, S. Business Value and Sustainability: An Integrated Supply Network Perspective; Palgrave Macmillan: London, UK, 2016.

24. CDP. Transport Report; Carbon Disclosure Project: London, UK, 2010.

25. Cashore, B.; Auld, G.; Newsom, D. Governing through Markets: Regulating Forestry through Non-state Environmental Governance; Yale University Press: New Haven, CT, USA, 2004.

26. Murphy, D.F.; Bendell, J. Partners in Time? Business, NGOs and Sustainable Development; United Nations Research Institute for Social Development: New York, NY, USA, 1999; pp. 1-71.

27. WRI/WBCSD. The Greenhouse Gas Protocol: A Corporate Accounting and Reporting Standard, Revised Editon; World Resources Insititue: Washington, DC, USA, 2011.

28. Lee, K.-H.; Herold, D.M. WBCSD \& EMAN: Measuring sustainability performance-Corporate approaches and contributions. In Carbon Performance Measurement and Reporting in Global Logistics Industry: Challenges and Collaboration Opportunities between Corporations and Academics; Irwin, R., Schaltegger, S., Eds.; WBCSD: Geneva, Switzeland, 2015; pp. 60-63.

29. FedEx. Fedex Annual Report; FedEx Corporation: Memphis, TN, USA, 2014.

30. UPS. Ups Annual Report 2013; UPS: Louisville, GA, USA, 2014.

31. McKinnon, A.; Piecyk, M. Setting targets for reducing carbon emissions from logistics: Current practice and guiding principles. Carbon Manag. 2012, 3, 629-639. [CrossRef]

32. CDP. Investor CDP 2015 Information Request_Fedex Corporation; Carbon Disclosure Project: London, UK, 2015. 
33. Deutsche Post DHL. We Deliver Responsibility: Corporate Social Responsibility Report; Deutsche Post DHL: Bonn, Germany, 2011.

34. CDP. Investor CDP 2015 Information Request_Ups; Carbon Disclosure Project: London, UK, 2015.

35. Schaltegger, S.; Csutora, M. Carbon accounting for sustainability and management. Status quo and challenges. J. Clean. Prod. 2012, 36, 1-16. [CrossRef]

36. European Commission. Carbon Footprint: What It Is and How to Measure It; EC: Geneva, Switcherland, 2007.

37. Schmidt, M. Carbon accounting and carbon footprint-More than just diced results? Int. J. Clim. Chang. Strateg. Manag. 2009, 1, 19-30. [CrossRef]

38. Guthrie, J.; Parker, L.D. Corporate social reporting: A rebuttal of legitimacy theory. Account. Bus. Res. 1989, 19, 343-352. [CrossRef]

39. Dowling, J.; Pfeffer, J. Organizational legitimacy: Social values and organizational behavior. Pac. Sociol. Rev. 1975, 18, 122-136. [CrossRef]

40. Lenssen, G.; Arenas, D.; Lacy, P.; Pickard, S.; Kolk, A.; Pinkse, J. Business and climate change: Emergent institutions in global governance. Corp. Gov. Int. J. Bus. Soc. 2008, 8, 419-429.

41. DiMaggio, P.J.; Powell, W.W. The iron cage revisited: Institutional isomorphism and collective rationality in organizational fields. Am. Socio. Rev. 1983, 48, 147-160. [CrossRef]

42. Schaltegger, S.; Burritt, R. Business cases and corporate engagement with sustainability: Differentiating ethical motivations. J. Bus. Ethics 2015. [CrossRef]

43. Bourdieu, P.; Wacquant, L.J. An Invitation Towards a Reflexive Sociology; Policy Press: Cambridge, UK, 1992.

44. Scott, W.R. Institutions and Organizations: Foundations for Organizational Science; Sage: London, UK, 1995.

45. Thornton, P.H. Markets from Culture: Institutional Logics and Organizational Decisions in Higher Education Publishing; Stanford University Press: Standford, CA, USA, 2004.

46. Lounsbury, M.; Ventresca, M. The new structuralism in organizational theory. Organization 2003, 10, 457-480. [CrossRef]

47. Suddaby, R.; Greenwood, R. Rhetorical strategies of legitimacy. Admin. Sci. Quarter. 2005, 50, 35-67. [CrossRef]

48. Greenwood, R.; Díaz, A.M.; Li, S.X.; Lorente, J.C. The multiplicity of institutional logics and the heterogeneity of organizational responses. Organ. Sci. 2010, 21, 521-539. [CrossRef]

49. Maguire, S.; Hardy, C.; Lawrence, T.B. Institutional entrepreneurship in emerging fields: Hiv/aids treatment advocacy in canada. Acad. Manag. J. 2004, 47, 657-679. [CrossRef]

50. D'Aunno, T.; Sutton, R.I.; Price, R.H. Isomorphism and external support in conflicting institutional environments: A study of drug abuse treatment units. Acad. Manag. J. 1991, 34, 636-661. [CrossRef]

51. Hoffman, A.J. Climate change strategy: The business logic behind voluntary greenhouse gas reductions. Calif. Manag. Rev. 2005, 47, 21-46. [CrossRef]

52. Reay, T.; Hinings, C.B. The recomposition of an organizational field: Healthcare in alberta. Organ. Stud. 2005, 26, 351-384. [CrossRef]

53. Carter, C.R.; Rogers, D.S. A framework of sustainable supply chain management: Moving toward new theory. Int. J. Phys. Distrib. Logist. Manag. 2008, 38, 360-387. [CrossRef]

54. Oberhofer, P.; Dieplinger, M. Sustainability in the transport and logistics sector: Lacking environmental measures. Bus. Strateg. Environ. 2014, 23, 236-253. [CrossRef]

55. Castelo Branco, M.; Eugénio, T.; Ribeiro, J. Environmental disclosure in response to public perception of environmental threats: The case of co-incineration in portugal. J. Commun. Manag. 2008, 12, 136-151. [CrossRef]

56. Hogan, J.; Lodhia, S. Sustainability reporting and reputation risk management: An australian case study. Int. J. Account. Inform. Manag. 2011, 19, 267-287. [CrossRef]

57. Michelon, G. Sustainability disclosure and reputation: A comparative study. Corp. Rep. Rev. 2011, 14, 79-96. [CrossRef]

58. Sridhar, K. Corporate conceptions of triple bottom line reporting: An empirical analysis into the signs and symbols driving this fashionable framework. Soc. Resp. J. 2012, 8, 312-326. [CrossRef]

59. UNEP/SustainAbility. Trust Us: The Global Reporters 2002 Survey of Corporate Sustainability Reporting; UNEP: London, UK, 2002.

60. Cormier, D.; Gordon, I.M. An examination of social and environmental reporting strategies. Account. Audit. Account. J. 2001, 14, 587-617. [CrossRef] 
61. Milne, M.J.; Tregidga, H.; Walton, S. The triple bottom line: Benchmarking New Zealand's early reporters. Uni. Auckland Bus. Rev. 2003, 5, 36-50.

62. Hammond, K.; Miles, S. Assessing quality assessment of corporate social reporting: UK perspectives. Account. Forum 2004, 28, 61-79. [CrossRef]

63. Laine, M. Meanings of the term 'sustainable development'in finnish corporate disclosures. Account. Forum 2005, 29, 395-413. [CrossRef]

64. Crawford, S.E.; Ostrom, E. A grammar of institutions. Am. Political Sci. Rev. 1995, 89, 582-600. [CrossRef]

65. Criado-Jiménez, I.; Fernández-Chulián, M.; Husillos-Carqués, F.J.; Larrinage-González, C. Compliance with mandatory environmental reporting in financial statements: The case of spain (2001-2003). J. Bus. Ethics 2008, 79, 245-262. [CrossRef]

66. Burritt, R.L.; Hahn, T.; Schaltegger, S. Towards a comprehensive framework for environmental management accounting: Links between business actors and ema tools. Austr. Account. Rev. 2002, 12, 39-50. [CrossRef]

67. Clark, C.E. Differences between public relations and corporate social responsibility: An analysis. Public Relat. Rev. 2000, 26, 363-380. [CrossRef]

68. IPIECA. Petroleum Industry Guidelines for Reporting Greenhouse Gas Emissions; International Petroleum Industry Environmental Conservation Association: London, UK, 2011.

69. Wooten, M.; Hoffman, A.J. Organizational fields: Past, present and future. In The Sage Handobook of Organizational Institutionalism; Greenwood, R., Oliver, C., Shalin-Andersson, K., Suddaby, R., Eds.; Sage: London, UK, 2008; pp. 130-147.

70. CDP. Investor CDP 2010 Information Request-Ups; Carbon Disclosure Project: London, UK, 2010.

71. CDP. Investor CDP 2011 Information Request_Deutsche Post AG; Carbon Disclosure Project: London, UK, 2011.

72. CDP. Investor CDP 2012 Information Request_Fedex Corporation; Carbon Disclosure Project: London, UK, 2012.

73. Hoffman, A.J. Getting Ahead of the Curve: Corporate Strategies That Address Climate Change; Pew Center on Global Climate Change: Airlington, VA, USA, 2006.

74. CDP. Investor CDP 2012 Information Request_Ups; Carbon Disclosure Project: London, UK, 2012.

75. CDP. Investor CDP 2014 Information Request_Deutsche Post AG; Carbon Disclosure Project: London, UK, 2014.

76. CDP. Investor CDP 2013 Information Request_Deutsche Post AG; Carbon Disclosure Project: London, UK, 2013.

77. CDP. Investor CDP 2011 Information Request_Ups; Carbon Disclosure Project: London, UK, 2011.

78. Bouteligier, S. Exploring the agency of global environmental consultancy firms in earth system governance. Int. Environ. Agreem. Politics Law Econ. 2011, 11, 43-61. [CrossRef]

79. O'Donovan, G. Environmental disclosures in the annual report: Extending the applicability and predictive power of legitimacy theory. Account. Audit. Account. J. 2002, 15, 344-371. [CrossRef]

80. CDP. Investor CDP 2015 Information Request-Deutsche Post AG; Carbon Disclosure Project: London, UK, 2015.

81. CDP. Investor CDP 2010 Information Request-Deutsche Post AG; Carbon Disclosure Project: London, UK, 2010.

82. CDP. Investor CDP 2010 Information Request-Fedex corporation; Carbon Disclosure Project: London, UK, 2010.

83. CDP. Climate Action and Profitability: CDP sEp 500 Climate Change Report 2014; CDP North America: New York, NY, USA, 2014.

84. Milne, M.J.; Patten, D.M. Securing organizational legitimacy: An experimental decision case examining the impact of environmental disclosures. Account. Audit. Account. J. 2002, 15, 372-405. [CrossRef]

(C) 2017 by the authors. Licensee MDPI, Basel, Switzerland. This article is an open access article distributed under the terms and conditions of the Creative Commons Attribution (CC BY) license (http:/ / creativecommons.org/licenses/by/4.0/). 